\title{
A perioperatív tápláltsági állapot mint kockázati tényező az onkológiai sebészetben
}

\author{
Kollár Dániel dr. - Benedek-Tóth Zoltán dr. - Drozgyik András dr. \\ Molnár F. Tamás dr. - Oláh Attila dr.
}

Petz Aladár Egyetemi Oktató Kórház,

Pécsi Tudományegyetem, Általános Orvostudományi Kar Sebészeti Tanszéke, Győr

\begin{abstract}
Bevezetés: A tumorsebészetben a malnutritio független rizikófaktor. A kockázatcsökkentés egyik fontos eleme a perioperatív tápláltsági állapot felmérésén alapuló klinikai táplálás. Az irodalomban jól dokumentált az időben végzett rizikószűrés fontossága, de ennek módja, különösen hazai környezetben, kidolgozatlanabb.

Célkitüzés: A malnutritio szempontjából esendőbb csoportot alkotó onkológiai sebészeti betegek azonosíthatóságának igazolása, a szúrési metódus vizsgálata.

Módszer: 2016. október és 2018. november között öt kórcsoportban (emlő, máj, pancreas, mellkas, gyomor-bél rendszer) az igazolt vagy gyanított malignitás, illetve gyulladásos bélbetegség miatt mútétre váró betegeket telemedicina-módszerrel kerestük fel. A rizikócsoportokat (nincs rizikó - alultápláltság valószínűsíthető - súlyos alultápláltság) a sebész és dietetikus által közösen vezetett 'Nutritional Risk Score 2002' (NRS 2002) szürő pontrendszerrel állapítottuk meg. Az NRS 2002 pontértékeket a posztoperatív lefolyással vetettük össze (kórházi tartózkodás, 30 napon belüli szövődmények Clavien-Dindo szerinti osztályozása). Prospektív vizsgálatunkban 1556 beteg szerepel. Eredmények: Az emlősebészeti betegek $(\mathrm{n}=314)$ 95,2\%-a rizikómentes. A májreszekcióra várók $(\mathrm{n}=79)$ 43\%-a valószínúleg vagy biztosan alultáplált. A hasnyálmirigymútétre előjegyzett betegek $(\mathrm{n}=122) 81,2 \%$-a emelt rizikójú. A kuratív célú pancreasreszekción átesett betegek pontértéke alacsonyabb, mint a palliatív mútétben részesülő́ké $(\mathrm{p}>0,05)$. A tüdőreszekcióra váró $(\mathrm{n}=219)$ betegeknél $40,7 \%$ került emelt rizikócsoportba. Az emelkedett NRS 2002 érték magasabb szövődményaránnyal járt $(\mathrm{p}<0,05)$. Béltraktust érintő mútétek $(\mathrm{n}=822)$ esetén a betegek $71,2 \%$-a valószínúleg vagy biztosan súlyosan alultáplált. Az előrehaladott tumorok és a szövődmények egyaránt erős összefüggést mutattak az NRS 2002 értékkel $(\mathrm{p}<0,01)$.

Következtetés : Az NRS 2002 szűrő́módszer prediktív értékkel bír mind a tumorstádium, mind a szövődmények tekintetében. Módszerünkkel időben felismerhető a fokozott rizikót jelentő betegcsoport, így a pontérték alapján célzott mesterséges táplálás tervezhető.

Orv Hetil. 2021; 162(13): 504-513.
\end{abstract}

Kulcsszavak: malnutritio, tömeges szűrés, daganatok, onkológiai mútét, telemedicina

\section{Perioperative nutritional state as a surgical risk in oncologic patients}

Introduction: Malnutrition is an independent risk factor in oncologic surgery. Perioperative screening and aimed clinical nutrition are key elements in risk reduction. The importance of timely screening has been well published, but its method is underdeveloped, especially in Hungary.

Objective: Evaluation of a malnutrition screening method to identify patients at risk in oncologic surgery.

Method: Patients were enrolled from October 2016 to November 2018 in five groups (breast, liver, pancreas, thoracic and gastrointestinal surgery). All patients awaiting surgery for suspected or proven malignancy or for inflammatory bowel disease were screened preoperatively via telephone (telemedicine). Probability for malnutrition (no risk - suspicion for malnutrition - severe malnutrition) was jointly assessed by surgeon and dietitian using Nutritional Risk Score 2002 (NRS 2002). Screening results were compared to the postoperative course (including length of stay and 30-day morbidity/mortality using Clavien-Dindo classification). A total of 1556 patients were identified prospectively.

Results: $95.2 \%$ of breast surgery patients $(\mathrm{n}=314)$ were not at risk. Malnutrition was suspected or detected in $43 \%$ of patients awaiting liver resection $(n=79)$. Increased risk is present in $81.2 \%$ of pancreatic surgery cases $(n=122)$. Pancreas resections with curative intent were associated with lower scores than in palliative operations $(p>0.05)$. 
$40.7 \%$ of the 219 patients scheduled for lung resection had increased malnutrition risk. Higher NRS 2002 resulted in increased morbidity rate $(\mathrm{p}<0.05)$. Surgery on the intestines was performed on 822 cases. $71.2 \%$ of them had suspected or severe malnutrition. Presence of advanced cancer and complication rate showed strong relations with increased NRS $2002(\mathrm{p}<0.01)$.

Conclusion: Screening with NRS 2002 has predictive value on both tumor stage and complications. Our method is sound to identify patients at malnutrition risk in time, and thus an aimed clinical nutrition therapy can be planned.

Keywords: malnutrition, mass screening, neoplasms, oncologic surgery, telemedicine

Kollár D, Benedek-Tóth Z, Drozgyik A, Molnár FT, Oláh A. [Perioperative nutritional state as a surgical risk in oncologic patients]. Orv Hetil. 2021; 162(13): 504-513.

(Beérkezett: 2020. július 10.; elfogadva: 2020. augusztus 3.)

\section{Rövidítések}

$\mathrm{BMI}=($ body mass index $)$ testtömegindex $; \mathrm{COPD}=($ chronic obstructive pulmonary disease) krónikus obstruktív tüdőbetegség; $\mathrm{EBM}=$ (evidence-based medicine) evidenciaalapú orvoslás; ESPEN $=($ European Society for Clinical Nutrition and Metabolism) Európai Klinikai Táplálkozási és Anyagcsere Társaság; LOS = (length of stay) a kórházi ellátás időtartama; NRS $2002=($ Nutritional Risk Score 2002) táplálkozási kockázati pontszám 2002; PTE ÁOK = Pécsi Tudományegyetem, Általános Orvostudományi Kar

Világszerte évente mintegy 7,6-8,8 millió ember hal meg malignus tumoros betegség következtében [1]. A fejlett világban minden harmadik ember daganatos lesz élete során, és minden negyedik ember halálát is ez okozza [2]. A tumorstádiumtól független tápláltsági és funkcionális hanyatlás egyaránt rosszabb kimenetelt jósol. A tápláltság és a mútéti teherbíró képesség kapcsolata ismert tapasztalati tény [3-7]. A malnutritio független sebészeti rizikófaktor, mely esetenként potenciálisan reverzíbilis. Ha a súlyos, senyvesztő alapbetegségú páciens szuboptimális tápláltsági állapotban kerül műtétre, akkor még az esetlegesen kuratív szándékú beavatkozás is nagyobb valószínúséggel lesz sikertelen [8-11]. A mútéti stresszre adott inadekvát szervezeti reakció következményei a szeptikus szövődmények, különösen az anastomosiselégtelenség és a gyakoribb perioperatív halálozás.

A malnutritio és a cachexia egyaránt nehezen definiálható fogalmak. Különböző kórházi osztályok eltérő beteganyagai és a kóros tápláltság variábilis definíciói alapján rendkívül széles spektrumon mozog a veszélyeztetett betegek aránya. A malnutritiót jelzó tényezők többek között az alacsony testtömegindex (body mass index BMI), az elhúzódó ideig tartó szuboptimális tápanyagbevitel és a testsúlycsökkenés [12-14].

A tápláltsági állapot vizsgálatára számos antropometriai, laborvizsgálat, kórjóslati index és szứrő kérdőív ismert (a teljesség igénye nélkül: testtájak körfogatának vagy a bőrredőnek a mérése, bioimpedancia-analízis, izomtömegmérés komputertomográfiával, Metabolikus Kockázat Szúrőmódszer, Maastricht Index, Nutritional Risk
Index, Subjective Global Assessment, Mini Nutritional Assessment, Controlling Nutritional Status, Prognostic Nutritional Index, Malnutrition Screening Tool, Malnutrition Universal Screening Tool, Short Nutritional Assessment Questionnaire, Perioperative Nutrition Score) [15-19]. Ezek experimentális környezetben változó hatékonysággal prognosztikus értékkel rendelkeznek, de a klinikumban széles körú rutinhasználatukat korlátozza a személyzet-, eszköz- és költségvonzatuk, illetve a beteg számára további kórházi megjelenést jelenthetnek [20].

Az ESPEN (European Society for Clinical Nutrition and Metabolism) munkacsoport közel két évtizede vezette be a 'Nutritional Risk Score 2002' (NRS 2002) szû́rővizsgálatot. A korábbi kérdő́ivek tapasztalati, teoretikus megközelítésével szemben a megalkotás során evidenciaalapú (EBM - evidence-based medicine) kritériumok érvényesültek. A tápláltsági állapotot taglaló 128 , randomizált, kontrollált prospektív vizsgálat eredményeinek statisztikai elemzése vezetett az új pontrendszerhez. Fokozatokra osztva szerepet kap egyrészt a testsúlyvesztés, a csökkent tápanyagfelvétel, a kóros BMI, másrészt a kezelendő betegség súlyossága is. Külön pont jár a 70 év feletti korosztálynak [21, 22]. Számolása során objektív paramétereket ellenőriznek, laborvizsgálat szükségtelen, nem invazív, könnyen reprodukálható, bármikor ismételhető, és külön költséggel nem jár [23].

Az NRS 2002 számolása: a károsodott tápláltsági állapot súlyosságához (0-3 pont) hozzáadjuk a kezelt betegség súlyosságát (0-3 pont), ehhez 70 év felett további 1 pontot adunk [21] (1. táblázat).

- 0-2 pont: nincs kimutatható alultápláltsági rizikó;

- 3-4 pont: az alultápláltság rizikója miatt dietetikusi véleményezés javasolt;

- 5-7 pont: súlyos alultápláltság, kiegészítő mesterséges táplálásra van szükség.

Vizsgálatunk során a következőkre kerestünk választ.

- Nemzetközi adatokkal összehasonlítva mennyire terhelt a magyarországi onkológiai sebészeti beteganyag a malnutritio szempontjából?

- Alkalmas-e az NRS 2002 telemedicina-alapú preoperatív rizikószúrésre? 
1. táblázat |A ’Nutritional Risk Score 2002' számolásának elemei

\begin{tabular}{|c|c|c|c|}
\hline Fokozat & Pont & $\begin{array}{l}\text { A tápláltsági állapot } \\
\text { károsodása }\end{array}$ & A betegség súlyossága \\
\hline Normál & 0 & Normál tápláltsági állapot & $\begin{array}{l}\text { Normál tápanyag- } \\
\text { igény }\end{array}$ \\
\hline Enyhe & 1 & $\begin{array}{l}\text { - >5\% súlycsökkenés } \\
3 \text { hónap alatt } \\
\text { vagy } \\
\text { - az elmúlt héten } \\
\text { a tápanyagfelvétel } \\
\text { a normális } 50-75 \% \text {-a alatt }\end{array}$ & $\begin{array}{l}\text { Csípőtáji törés, } \\
\text { krónikus osztály } \\
\text { betegei, cirrhosis } \\
\text { hepatis, COPD, } \\
\text { hemodialízis, } \\
\text { diabetes mellitus, } \\
\text { onkológiai betegek }\end{array}$ \\
\hline Közepes & 2 & $\begin{array}{l}\text { - }>5 \% \text { súlycsökkenés } \\
2 \text { hónap alatt } \\
\text { vagy } \\
\text { - BMI } 18,5-20,5 \mathrm{~kg} / \mathrm{m}^{2} \\
\text { között } \\
\text { vagy } \\
\text { - az elmúlt héten } \\
\text { a tápanyagfelvétel } \\
\text { a normális } 25-60 \% \text {-a alatt }\end{array}$ & $\begin{array}{l}\text { Testüreg megnyitá- } \\
\text { sával járó mútét } \\
\text { Stroke } \\
\text { Súlyos pneumonia } \\
\text { Májat érintő } \\
\text { malignus tumor }\end{array}$ \\
\hline Súlyos & 3 & $\begin{array}{l}\text { - >5\% súlycsökkenés } \\
1 \text { hónap alatt } \\
\text { vagy } \\
\text { - > } 15 \% \text { súlycsökkenés } \\
3 \text { hónap alatt } \\
\text { vagy } \\
\text { - BMI <18,5 kg/m² } \\
\text { vagy } \\
\text { - az elmúlt héten } \\
\text { a tápanyagfelvétel } \\
\text { a normális } 0-25 \%-a\end{array}$ & $\begin{array}{l}\text { Fejsérülés } \\
\text { Csontvelőtransz- } \\
\text { plantált beteg } \\
\text { Intenzív kezelésben } \\
\text { részesülő beteg }\end{array}$ \\
\hline$<70$ év & 0 & & \\
\hline$\geq 70$ év & 1 & & \\
\hline
\end{tabular}

$\mathrm{BMI}=$ testtömegindex $; \mathrm{COPD}=$ krónikus obstruktív tüdőbetegség

- Az onkológiai sebészeti mútét előtti, NRS 2002 teszttel felmért alultápláltsági rizikó milyen összefüggést mutat a posztoperatív kórlefolyással?

\section{Módszer}

A prospektív adatgyújtést a Petz Aladár Egyetemi Oktató Kórház Sebészeti Osztályán (PTE ÁOK, Sebészeti Tanszék) 2016. október és 2018. november között végeztük.

A noninvazív vizsgálat protokollját a Petz Aladár Egyetemi Oktató Kórház Regionális Tudományos és Kutatásetikai Bizottsága a 76-1-33-/2016 hivatkozási számmal hagyta jóvá.

Öt témakörben (emlő-, máj-, pancreas-, gyomor-bél rendszeri és mellkassebészeti mútétek) egyoldalas formanyomtatványon regisztráltuk a malignus betegség gyanúja, igazolt malignitás, illetve gyulladásos bélbetegség miatt mútétre váró felnőtt betegek demográfiai, komorbiditási és mútéti adatait. Külön vizsgáltuk a fenti betegségkörökbe tartozó elektív és az akut mútétre kerülő betegeket. Elsődleges végpontnak a gyógyulást, illetve a halálozást, másodlagos végpontnak pedig a 30 napon belüli szövődményt és a mútétet követő kórházi tartózkodást vettük.

A betegeket az NRS 2002 pontrendszer (0-7 pont) alapján, telemedicinális módszer igénybevételével soroltuk malnutritio-rizikócsoportokba. Az 1. táblázat elemeinek figyelembevételével a mütéti előjegyzés után a formanyomtatványon a sebész megbecsülte a kórelőzmény, a 'staging' vizsgálatok és a tervezett beavatkozás alapján a betegség súlyosságát (1-3 pont) (például a hasüreg megnyitásával járó tumorreszekciós mútét: 2 pont). Ezután a dietetikus telefonon vette fel a kapcsolatot a beteggel, és a beszélgetés során nyert általános és táplálkozási anamnézis alapján sorolta be a károsodott tápláltsági állapotot (0-3 pont). A hetvenéves életkort elérő betegeink további 1 pontot kaptak.

Az összesített pont alapján meghatároztunk alacsony (1-2 pont), közepes (3-4 pont) és magas rizikójú csoportot (5-7 pont).

A mütéti beavatkozás típusán, a beavatkozást követő kórházi tartózkodási időn (LOS) kívül a szövődményeket a posztoperatív 30. napig követtük. A mútét utáni szövődmények súlyosság szerinti osztályozására a széles körben elfogadott Clavien-Dindo-klasszifikációt alkalmaztuk [24, 25] (2. táblázat). A mortalitás megegyezik az V. kategóriájú szövődmény számértékével. Vizsgálatunk során nem tettünk különbséget az alapbetegség(ek) bôl és a mütéti beavatkozásból adódó szövődmények között.

A végleges hisztológiai lelet és a szükség szerinti 'staging' vizsgálat alapján állapítottuk meg a malignitás tényét és azt, hogy beavatkozásunkat kuratív vagy palliatív jellegưnek tekintjük-e.

Pearson-, Kendall tau- és Spearman rhó-statisztikai próbákkal számoltuk ki, hogy az NRS 2002 score össze-

\begin{tabular}{ll} 
2. táblázat & $\begin{array}{l}\text { A mútét utáni szövődmények Clavien-Dindo szerinti klasszifi- } \\
\text { kácioja }\end{array}$ \\
\hline Kategória & Meghatározás \\
\hline I. & $\begin{array}{l}\text { A normál posztoperatív lefolyástól való bármilyen } \\
\text { eltérés, mely nem igényel gyógyszeres vagy invazív } \\
\text { beavatkozást. Idetartozik az ágy melletti sebfeltárás. } \\
\text { (Megengedett a fájdalomcsillapítók, hányingercsökken- } \\
\text { tók alkalmazása.) }\end{array}$ \\
\hline II. & $\begin{array}{l}\text { A fenti kategóriába nem tartozó gyógyszerek szüksége, } \\
\text { illetve transzfúzió, parenteralis táplálás, egyéb sebfertő- } \\
\text { zés. }\end{array}$ \\
\hline IIIa & $\begin{array}{l}\text { Sebészi, radiológiai vagy endoszkópos intervenció } \\
\text { szükségessége nem általános érzéstelenítésben. }\end{array}$ \\
\hline IIIb & $\begin{array}{l}\text { Sebészi, radiológiai vagy endoszkópos intervenció } \\
\text { szükségessége általános érzéstelenítésben. }\end{array}$ \\
\hline IVa & $\begin{array}{l}\text { Életveszélyes szövődmény, intenzív terápia szüksége, } \\
\text { egyszervi elégtelenség. }\end{array}$ \\
\hline IVb & $\begin{array}{l}\text { Életveszélyes szövődmény, intenzív terápia szüksége, } \\
\text { többszervi elégtelenség. }\end{array}$ \\
\hline Halál.
\end{tabular}


függésben áll-e a posztoperatív szövődményekkel. Student-féle t-próbával ellenőriztük a tumorstádium és a szövődmények kapcsolatát. A szignifikanciahatárt $\mathrm{p}<0,05$ értékben rögzítettük. Erős szignifikancia $\mathrm{p}<0,01$ esetén áll fenn.

A vizsgálat során az öt kórcsoportban perioperatív (mûtét előtti és a kórházi tartózkodás alatt ismételt) tápláltságirizikó-felmérést összesen 1556 betegnél végeztünk. A beteganyag a profilok szerint a következőképpen oszlott el.

A) Emlősebészet: 314 beteg.

- Igazolt malignitás: 296 eset (94,3\%);

- malignitás nem igazolódott (benignus, kontrollcsoport): 18 eset $(5,7 \%)$.

B) Májsebészet: 79 beteg.

- Primer malignus májtumor: 17 eset $(21,5 \%)$;

- májmetasztázis: 53 eset $(67,1 \%)$;

- malignitás nem igazolódott (benignus, kontrollcsoport): 9 eset $(11,4 \%)$.

C) Pancreassebészet: 122 beteg.

- Igazolt malignitás, kuratív célú reszekció: 49 eset $(40,1 \%)$;

- előrehaladott malignus kórkép miatti palliatív műtét: 54 eset $(44,3 \%)$;

- malignitás nem igazolódott (benignus, kontrollcsoport): 19 eset $(15,6 \%)$.

D) Mellkassebészet: 219 beteg.

- Igazolt malignitás, kuratív célú reszekció: 139 eset $(63,5 \%)$;

- előrehaladott malignus kórkép miatti palliatív mütét: 53 eset $(24,2 \%)$;

- malignitás nem igazolódott (benignus, kontrollcsoport): 27 eset (12,3\%).

E) Gyomor-bél rendszeri sebészet: 822 beteg.

- Igazolt malignitás, kuratív célú reszekció: 455 eset $(55,3 \%)$;

- előrehaladott malignus kórkép miatti palliatív mútét: 226 eset $(27,5 \%)$;
- malignitás nem igazolódott (benignus, kontrollcsoport): 141 eset $(17,2 \%)$.

Elektív mütét 698 betegnél $(84,9 \%)$, akut mútét 124 betegnél $(15,1 \%)$ történt.

\section{Eredmények}

Tapasztalataink szerint a dietetikusi állapotfelmérés telemedicina-módszerrel minimum 5 , maximum 30 percet vesz igénybe, az esetek $>90 \%$-ában 10 perc alatt elvégezhető.

A) Az emlősebészeti mútétre kerülő betegek körében az NRS 2002 alapján a malnutritio szempontjából a betegek 95,2\%-a az alacsony rizikójú tartományba tartozik. 4,8\% esetén kóros tápláltság valószínüsíthető. Súlyosan alultáplált esetet nem regisztráltunk (3. táblázat).

B) A májsebészeti mútétre kerülő betegek körében az NRS 2002 alapján a betegek 57,0\%-a az alacsony rizikójú tartományba tartozik. 41,7\%-ban malnutritio valószínúsíthető, 1,3\%-ban súlyos alultápláltság áll fenn (4. táblázat).

C) A pancreassebészeti mútétre kerülő betegek körében az NRS 2002 alapján a malnutritio szempontjából a betegek $18,8 \%$-a az alacsony rizikójú tartományba tartozik. 76,2\%-ban kóros tápláltság valószínúsíthető, 5\%ban súlyos alultápláltság áll fenn.

Ha a reszekciós mútét önmagában radikális/gyógyító jellegú (malignus betegség kuratív R0-reszekciója vagy benignus hisztológia), akkor az alacsony rizikójú csoportba a betegek $23,5 \%$-a, a valószínüsíthetően alultáplált csoportba a 70,6\%-a, a súlyosan alultáplált csoportba az 5,9\%-a tartozik. Amennyiben elörehaladott malignitás miatt történik beavatkozás (palliatív mütét), akkor az alacsony rizikójú csoportba $13,0 \%$, a valószínúsíthetően alultáplált csoportba $83,3 \%$, a súlyosan alultáplált csoportba 3,7\% tartozik (5. táblázat).

A pancreassebészeti beavatkozások esetén az átlagos NRS 2002 pontérték az előrehaladott malignitás miatt

3. táblázat |Az emlőmútéten átesett betegek 'Nutritional Risk Score 2002' alapján történő rizikóbeosztása

\begin{tabular}{|c|c|c|c|c|c|c|c|c|}
\hline \multirow[b]{2}{*}{ Emlö } & \multirow[b]{2}{*}{$\mathrm{n}(\%)$} & \multicolumn{5}{|c|}{ A 'Nutritional Risk Score 2002' értéke } & \multirow[b]{2}{*}{ Átlag } & \multirow[b]{2}{*}{ Szórás } \\
\hline & & 1 & 2 & 3 & 4 & $>4$ & & \\
\hline Összes eset & $314(100)$ & $202(64,3)$ & $97(30,9)$ & $14(4,5)$ & $1(0,3)$ & $0(0)$ & 1,407 & 0,592 \\
\hline Malnutritio-rizikó & $314(100)$ & \multicolumn{2}{|c|}{$\begin{array}{c}\text { Alacsony } \\
299(95,2)\end{array}$} & \multicolumn{2}{|c|}{$\begin{array}{c}\text { Valószínú } \\
15(4,8)\end{array}$} & $\begin{array}{c}\text { Biztos } \\
0(0)\end{array}$ & & \\
\hline
\end{tabular}

4. táblázat | A májreszekción átesett betegek 'Nutritional Risk Score 2002' alapján történő rizikóbeosztása

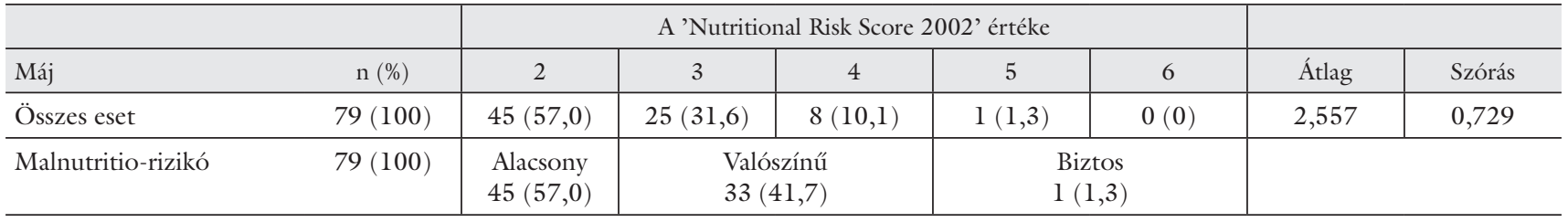


5. táblázat |A pancreassebészeti betegek 'Nutritional Risk Score 2002' alapján történő rizikóbeosztása

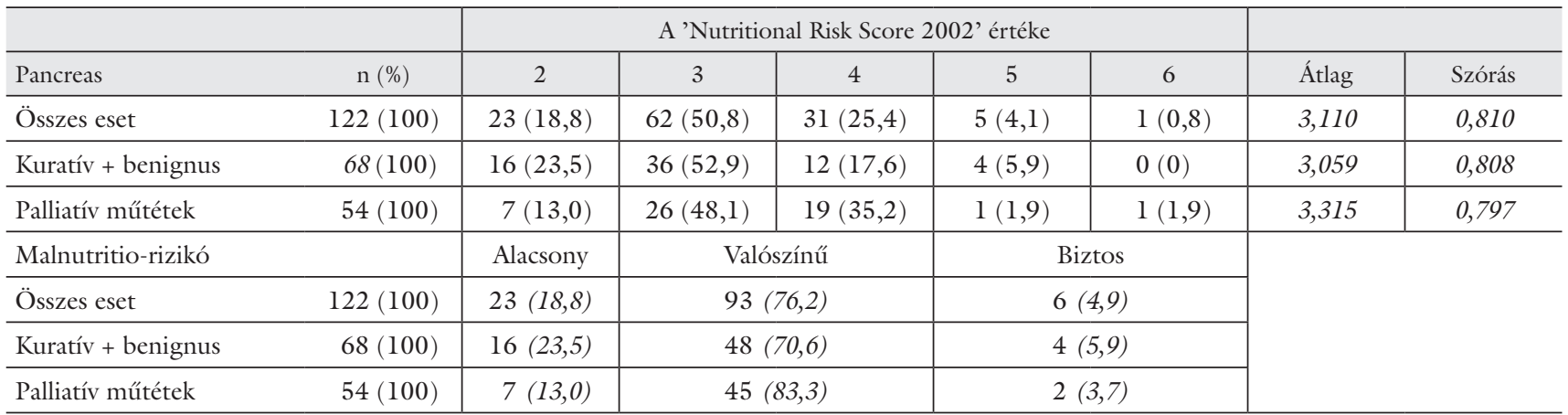

végzett palliatív mútéteknél $(\mathrm{n}=54)$ a legmagasabb $(3,315 \pm 0,797)$. Az összes esetre $(n=122)$ vonatkoztatott átlagos érték ennél alacsonyabb $(3,110 \pm 0,810)$, míg a radikális reszekción átesett betegeknél a legalacsonyabb $(3,059 \pm 0,808)$.

A khi-négyzet-próbával, Wilcoxon-próbával és Szmirnov-teszttel végzett homogenitásvizsgálatok alapján a fenti átlagos NRS 2002 értékek homogének, közöttük szignifikáns különbség nem igazolható $(p>0,05)$.

D) A mellkassebészeti mütétre kerülő betegek körében az NRS 2002 alapján a malnutritio szempontjából a betegek $59,4 \%$-a az alacsony rizikójú tartományba tartozik. 40,2\%-ban kóros tápláltság valószínúsíthetó, 0,5\%-ban súlyos alultápláltság áll fenn.
A kuratív tumormútétcsoportba a malignus hisztológiájú, távoli szervbe áttétet nem adó tumorok R0-reszekciója került (139 mútét). A palliatív/diagnosztikus mútéti csoportba azon betegeket vettük, akiknél a narkózisban történt sebészi mintavétel és/vagy pleurodesis természetszerúleg nem járt tumorszövet-eradikációval (53 eset). A végleges hisztológia alapján benignus betegséget igazoló csoportot külön tüntetjük fel (27 eset) (6. táblázat).

A tüdőreszekciós mútétet követő kórházi tartózkodás napjainak számát és a 30 napon belüli szövődmények súlyosságát a 7. táblázat mutatja.

A malignus tüdőtumor miatt végzett R0-reszekciók (139 eset) és benignus hisztológiájú mútétek (27 eset)

6. táblázat |A tüdőcsonkolással járó sebészeti esetek 'Nutritional Risk Score 2002' alapján történő rizikóbeosztása

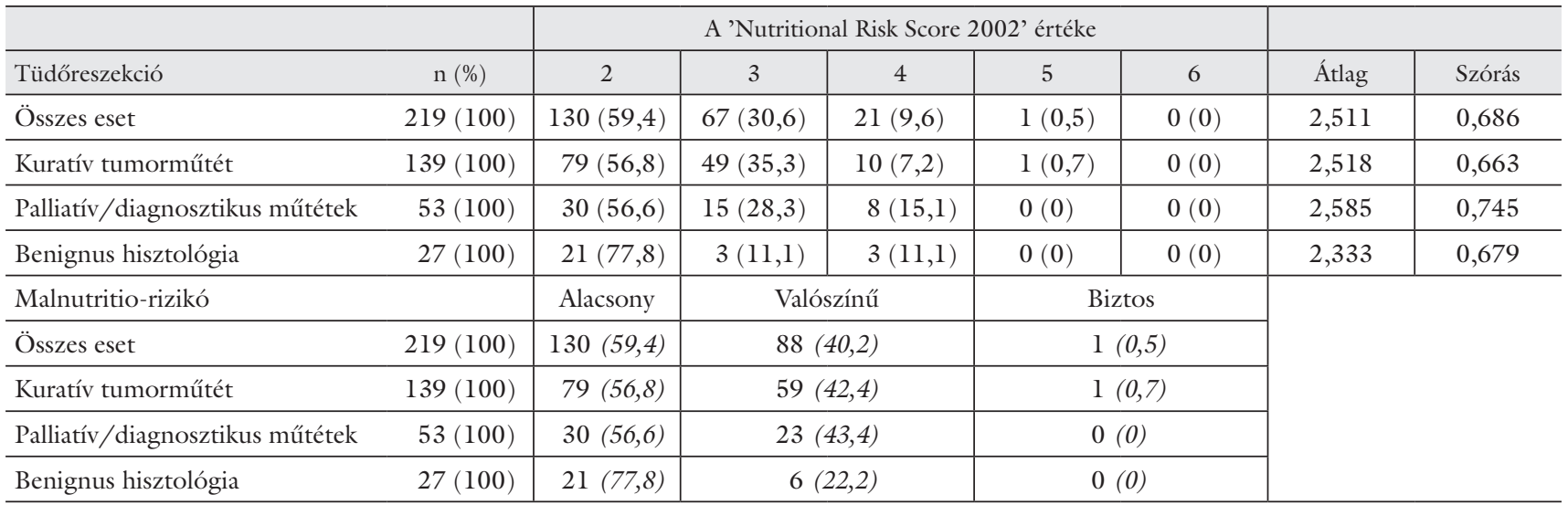

7. táblázat | Tüdőcsonkolás után a 30 napon belüli szövődmények gyakorisága és a kórházi tartózkodási idő

\begin{tabular}{|c|c|c|c|c|c|c|c|c|}
\hline \multirow[b]{2}{*}{ Tüdőreszekció } & \multirow[b]{2}{*}{$\mathrm{n}(\%)$} & \multicolumn{5}{|c|}{ Clavien-Dindo-klasszifikáció } & \multicolumn{2}{|c|}{ LOS (nap) } \\
\hline & & I. & II. & III. & IV. & $\mathrm{V}$. & Átlag & Szórás \\
\hline Összes eset & $219(100)$ & $14(6,4)$ & $41(18,7)$ & $28(12,8)$ & $2(0,9)$ & $4(1,8)$ & 5,169 & 3,065 \\
\hline Kuratív tumormútét & $139(100)$ & $7(5,0)$ & $28(20,1)$ & $24(17,3)$ & $1(0,7)$ & $4(2,9)$ & 5,669 & 3,227 \\
\hline Palliatív/diagnosztikus mútétek & $53(100)$ & $6(11,3)$ & $8(15,1)$ & $3(5,7)$ & $1(1,9)$ & $0(0)$ & 4,396 & 2,817 \\
\hline Benignus hisztológia & $27(100)$ & $1(3,7)$ & $5(18,5)$ & $1(3,7)$ & $0(0)$ & $0(0)$ & 4,111 & 1,987 \\
\hline Szövődmény & & \multicolumn{2}{|c|}{ Enyhe } & \multicolumn{3}{|c|}{ Súlyos } & & \\
\hline
\end{tabular}

LOS = a kórházi ellátás időtartama 
8. táblázat |A gyomor-bél rendszeri sebészeti betegek 'Nutritional Risk Score 2002' alapján történő rizikóbeosztása

\begin{tabular}{|c|c|c|c|c|c|c|c|c|}
\hline & & \multicolumn{5}{|c|}{ A 'Nutritional Risk Score 2002' értéke } & \multirow[b]{2}{*}{ Átlag } & \multirow[b]{2}{*}{ Szórás } \\
\hline Gyomor-bél rendszer & $\mathrm{n}(\%)$ & 2 & 3 & 4 & 5 & 6 & & \\
\hline Összes eset & $822(100)$ & $237(28,8)$ & $353(42,9)$ & $197(24,0)$ & $32(3,9)$ & $3(0,4)$ & 3,039 & 0,848 \\
\hline Kuratív tumormútét & $455(100)$ & $146(32,1)$ & $189(41,5)$ & $103(22,6)$ & $15(3,3)$ & $2(0,4)$ & 2,985 & 0,849 \\
\hline Palliatív mútétek & $226(100)$ & $35(15,5)$ & $103(45,6)$ & $73(32,3)$ & $14(6,2)$ & $1(0,4)$ & 3,305 & 0,822 \\
\hline Benignus hisztológia & $141(100)$ & $56(39,7)$ & $61(43,3)$ & $21(14,9)$ & $3(2,1)$ & $0(0)$ & 2,787 & 0,782 \\
\hline Malnutritio-rizikó & & Alacsony & \multicolumn{2}{|c|}{ Valószínú } & \multicolumn{2}{|c|}{ Biztos } & & \\
\hline Összes eset & $822(100)$ & $237(28,8)$ & \multicolumn{2}{|c|}{$550(66,9)$} & \multicolumn{2}{|c|}{$35(4,3)$} & & \\
\hline Kuratív tumormútét & $455(100)$ & $146(32,1)$ & \multicolumn{2}{|c|}{$292(64,2)$} & \multicolumn{2}{|c|}{$17(3,7)$} & & \\
\hline Palliatív mütétek & $226(100)$ & $35(15,5)$ & \multicolumn{2}{|c|}{$176(77,9)$} & \multicolumn{2}{|c|}{$15(6,6)$} & & \\
\hline Benignus hisztológia & $141(100)$ & $56(39,7)$ & \multicolumn{2}{|c|}{$82(58,2)$} & \multicolumn{2}{|c|}{$3(2,1)$} & & \\
\hline
\end{tabular}

NRS 2002 értékei és a 30 napon belüli szövődmények súlyosságát jelző Clavien-Dindo-osztályok közötti öszszefüggések vizsgálata (szignifikanciaszint $\mathrm{p}<0,05$ határral):

- Pearson-féle korreláció (NRS 2002 vs. ClavienDindo) $=0,033$;

- Kendall-tau-koefficiens (NRS 2002 vs. ClavienDindo) $=0,018$

- Spearman-rhó-koefficiens (NRS 2002 vs. ClavienDindo $)=0,018$.

A Pearson-, Kendall-tau- és Spearman-rhó-tesztek alapján az NRS 2002 magasabb értékéhez szignifikánsan magasabb Clavien-Dindo-értékek járnak. Ez alapján az alultápláltság magasabb rizikója súlyosabb szövődményekkel jár.

E) Gyomor-bél rendszeri sebészet: az adatgyújtési időszakban összesen 822 rizikószürést végeztünk az NRS 2002-vel. A teljes kohorsz inhomogén, ugyanis szerepel benne elektív és akut mütét is, gyomorreszekciók, vékonybél- és vastagbélmütétek egyaránt, a végleges szövettan alapján benignus és malignus kórképek, illetve többszervi reszekciók is. A teljes beteganyag NRS 2002 és Clavien-Dindo-értékei a 8. és a 9. táblázatban láthatók.

9. táblázat A gyomor-bél rendszer mútéte utáni 30 napon belüli szövődmények gyakorisága

\begin{tabular}{|c|c|c|c|c|c|c|}
\hline & & \multicolumn{5}{|c|}{ Clavien-Dindo-klasszifikáció } \\
\hline $\begin{array}{l}\text { Gyomor-bél } \\
\text { rendszer }\end{array}$ & $\mathrm{n}(\%)$ & I. & II. & III. & IV. & V. \\
\hline Összes eset & $\begin{array}{c}822 \\
(100)\end{array}$ & $\begin{array}{c}83 \\
(10,1)\end{array}$ & $\begin{array}{c}126 \\
(15,3)\end{array}$ & $\begin{array}{c}36 \\
(4,4)\end{array}$ & $\begin{array}{c}14 \\
(1,7)\end{array}$ & $\begin{array}{c}26 \\
(3,2)\end{array}$ \\
\hline $\begin{array}{l}\text { Kuratív } \\
\text { tumormütét }\end{array}$ & $\begin{array}{c}455 \\
(100)\end{array}$ & $\begin{array}{c}54 \\
(11,9)\end{array}$ & $\begin{array}{c}79 \\
(17,4)\end{array}$ & $\begin{array}{c}15 \\
(3,3)\end{array}$ & $\begin{array}{c}8 \\
(1,8)\end{array}$ & $\begin{array}{c}6 \\
(1,3)\end{array}$ \\
\hline Palliatív mútétek & $\begin{array}{c}226 \\
(100)\end{array}$ & $\begin{array}{c}16 \\
(7,1)\end{array}$ & $\begin{array}{c}34 \\
(15)\end{array}$ & $\begin{array}{c}11 \\
(4,9)\end{array}$ & $\begin{array}{c}3 \\
(1,3)\end{array}$ & $\begin{array}{c}19 \\
(8,4)\end{array}$ \\
\hline $\begin{array}{l}\text { Benignus } \\
\text { hisztológia }\end{array}$ & $\begin{array}{c}141 \\
(100)\end{array}$ & $\begin{array}{c}13 \\
(9,2)\end{array}$ & $\begin{array}{c}13 \\
(9,2)\end{array}$ & $\begin{array}{c}10 \\
(7,1)\end{array}$ & $\begin{array}{c}3 \\
(2,1)\end{array}$ & $\begin{array}{c}1 \\
(0,7)\end{array}$ \\
\hline Szövődmény & & \multicolumn{2}{|c|}{ Enyhe } & \multicolumn{3}{|c|}{ Súlyos } \\
\hline
\end{tabular}

Az NRS 2002 pontok átlagát és átlagszórását Studentféle kétmintás t-próbával elemezve, a benignus hisztológiával operált betegek $(2,787 \pm 0,782)$, a kuratív céllal végzett reszekciók $(2,985 \pm 0,849)$ és a palliatív mútétek $(3,305 \pm 0,822)$ csoportjai egymással párosítva erősen szignifikáns különbséget mutatnak $(\mathrm{p}<0,01)$. Eszerint a malignus tumor jelenléte és ehhez képest az előrehaladott stádiumú (sebészileg inkurábilis) tumor egyaránt magasabb NRS 2002 értékkel jár. Az összes beteg 71,2\%ának van NRS $2002 \geq 3$ értéke. Ugyanez az arány kuratív tumorreszekció esetén $67,9 \%$, palliatív mütétnél 84,5\%, benignus szövettannál $60,3 \%$.

A Pearson-féle teszt alapján az NRS 2002 pontérték és a 30 napos Clavien-Dindo-szövődmény súlyossága között erôsen szignifikáns $(\mathrm{p}=0,004)$ pozitív korreláció van.

A Clavien-Dindo-pontok eloszlása a fenti csoportokban Student-féle t-próbával elemezve: a kuratív célú tumorreszekciók és a benignus hisztológia miatti mútétek között nincs szignifikáns különbség $(\mathrm{p}=0,19)$. A malignus betegség miatt, de csak palliatív beavatkozást engedő és a benignus szövettanú mütétek között erősen szignifikáns a különbség $(\mathrm{p}=0,005)$. A tumoros betegek közül a kuratív reszekción átesettek és a sebészileg inkurábilis esetek között erősen szignifikáns a különbség ( $\mathrm{p}=$ $0,002)$.

Amennyiben a 822 beteg csoportosítását aszerint végezzük el, hogy elektív vagy akut mútétben részesültek, akkor a malnutritio rizikója, a szövődmények és a LOS a 10. és 11. táblázatban közöltek szerint alakul.

Az akut mútétre kerülő betegek összesen 88,8\%-a, elektív mütét esetén $68,0 \%$-a a malnutritio szempontjából emelt szintű rizikócsoportba tartozik, az NRS 2002 pontok különbsége erősen szignifikáns $\left(\mathrm{p}=6 \times 10^{-5}\right)$. Az összes eset NRS 2002 értéke erősen szignifikánsan alacsonyabb, mint az akut mútéteké $(\mathrm{p}=0,0004)$.

A szövődmények aránya t-próbával erősen szignifikáns különbséget mutat az összes eset versus akut mütétek esetén $\left(\mathrm{p}=10^{-8}\right)$ és az elektív versus akut mütétek esetén is $\left(\mathrm{p}=10^{-12}\right)$. A LOS t-próbával erősen szignifikáns 
10. táblázat |A gyomor-bél rendszeri sebészeti betegek ’Nutritional Risk Score 2002' alapján történő rizikóbeosztása

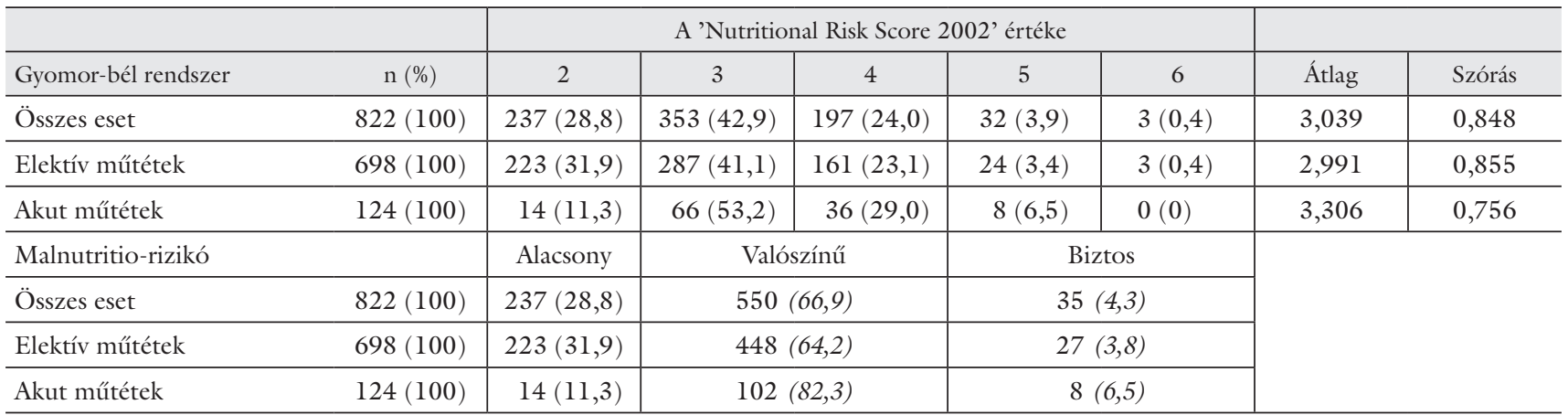

11. táblázat |A gyomor-bél rendszer mútéte utáni 30 napon belüli szövődmények gyakorisága és a kórházi tartózkodási idő

\begin{tabular}{lc|c|c|c|c|c|c|c}
\hline & & \multicolumn{3}{c|}{ Clavien-Dindo-klasszifikáció } & \multicolumn{2}{c}{ LOS (nap) } \\
\hline Gyomor-bél rendszer & $\mathrm{n}(\%)$ & I. & II. & III. & IV. & V. & Átlag & Szórás \\
\hline Összes eset & $822(100)$ & $83(10,1)$ & $126(15,3)$ & $36(4,4)$ & $14(1,7)$ & $26(3,2)$ & 7,718 & 3,938 \\
\hline Elektív mútétek & $698(100)$ & $60(8,6)$ & $104(14,9)$ & $25(3,6)$ & $7(1)$ & $15(2,1)$ & 7,549 & 3,675 \\
\hline Akut mútétek & $124(100)$ & $23(18,5)$ & $22(17,7)$ & $11(8,9)$ & $7(5,6)$ & $11(8,9)$ & 8,669 & 5,087 \\
\hline Szövő́dmény & \multicolumn{3}{|c|}{ Enyhe } & \multicolumn{7}{c|}{ Súlyos } & & \\
\hline
\end{tabular}

LOS = a kórházi ellátás időtartama

különbséget mutat az összes eset versus akut mútétek ( $\mathrm{p}=0,008)$ és az elektív versus akut mütétek esetén is $(\mathrm{p}=0,001)$

Az akut mütétek az NRS 2002, a szövődmények és a LOS tekintetében is a legrosszabb értékeket mutató csoportot alkotják.

\section{Megbeszélés}

Minden invazív beavatkozás (sebészeti trauma) inflammatorikus aktiválódást és komplex metabolikus választ okoz, melyek következménye egyebek között a fokozott tápanyagfelvételi igény [26]. Az onkológiai sebészetben ez többé-kevésbé arányos a mútéti terheléssel.

A sebészeti technika és a gyógyítandó betegség súlyossága, stádiuma egyaránt fontos faktor a kimenetelben. Nem lehet azonban figyelmen kívül hagyni a harmadik tényezőt, nevezetesen a beteg teherbírását. Az utóbbit pedig már a mútétre való felkészülés során optimalizálni kell. A napjainkban zajló paradigmaváltás eredménye a prehabilitáció hangsúlyossá válása. Az eleve meglévő és az (invazív) beavatkozás során kialakult szervkárosodásokra adott reaktív modell helyett az ugyanezen tényezők ellensúlyozását célzó proaktív szemlélet hódít teret [27]. Egyre bővülő irodalom támogatja a táplálkozási, mozgásszervi és pszichés felkészítés jótékony hatását mind hasi, mind mellkasi onkológiai sebészetben [2831]. Jó compliance esetén megfelelő felkészítéssel a mütéti morbiditás és mortalitás is csökkenthető. Az egyénre szabott, sikeres prehabilitáció a rövid (posztoperatív szövődmények) és a hosszú távú (teljes restitúció) eredmé- nyek javulásában hálálja meg magát. A jelenség súlya Magyarországon sem ismeretlen (Csiba és mtsai [32] és www.fitpuli.hu).

Az ESPEN által kidolgozott, 2017. évi mesterséges táplálási vezérfonal [17] ajánlása alapján nagy műtét előtt és után egyaránt szükséges a tápláltsági állapot felmérése. Malnutritio esetén már minimum 7-14 nappal a tervezett mütét előtt szükséges a mesterséges táplálás megkezdése [33]. A perioperatív időszakban alultápláltság veszélye esetén dietetikusi vizsgálat is javasolt, szükség esetén a táplálás az emissziót követően is folytatandó. A hazánkban hatályos „klinikai egészségügyi szakmai irányelv" az ESPEN-konszenzus főbb gondolatait magyar viszonylatra honosította [34], és javaslatot tett táplálási teamek felállítására [35]. A szükséges módszerek és infrastruktúra kidolgozásáról ajánlás nincs, az anyagi feltételek pedig hiányoznak.

Az egészségügyi és gazdasági szempontból is szerencsésebb helyzetben lévő Ausztria és Svájc területén végzett felmérés alapján a kórházak 30\%-ában egyáltalán nem történik preoperatív tápláltságiállapot-felmérés, míg kórházi felvételkor vagy mütét után történő felmérés is csak 48\%-ban fordul elő [36]. Egy Európa 25 országára - köztük hazánkra is - kiterjedő felmérés szerint a kórházi betegek 27\%-a tartozik a malnutritio szempontjából rizikócsoportba, ennek ellenére a vizsgált 325 kórháznak csak az 52\%-ában volt rutinszerû tápláltságiállapot-szürés [37]. Ráadásul a homályos definíciók miatt az alultápláltság veszélyét is más-más kritériumrendszer alapján állítják fel a gyógyintézetek [38]. 
Számos vizsgálat igazolta, hogy a tumoros betegeknél a malnutritiót jelző magasabb NRS 2002 érték rosszabb prognózist vetít előre. Az onkológiai vizsgálatok végpontjainak számító betegségmentes túlélés, progressziómentes túlélés, túlélés teljes időtartama is korrelációt mutat a kezelés során regisztrált NRS 2002 értékkel, és egyes vizsgálatok szerint független prognosztikai faktorként is szerepel $[39,40]$.

Amennyiben az NRS $2002 \geq 3$ pont, a posztoperatív szövődmények, a mortalitás és a kórházi tartózkodás emelkedésével kell számolni, emiatt a mesterséges táplálás megfontolandó [23, 38, 41-45]. Az NRS 2002 számolásához szükséges adatok a betegek 95-99\%-ánál nyerhetők, egy átlagos felmérés 10 percnél kevesebb időt vesz igénybe $[23,46]$. Az orvosok és a nővérek az egyéb irányú terhelés mellett alacsony hatásfokkal használják a szưrő kérdőíveket, miközben a dietetikus kezében hasznos módszernek bizonyul [47].

A modell feltételezi a protokolláris dietetikusi állapotfelmérést, melynek több korlátja is van. A túlterhelt járóbeteg-ellátásban a rizikónak kitett betegek mütéti előjegyzésekor a valóságban irreális remény, hogy valós tápláltsági statust rögzítsenek. Ha az első - tájékozódó - felmérés a kórházi felvételkor történik, nővéri kompetenciaként, az ESPEN 'guideline' alapján már eleve későn kerül látótérbe a beteg, a korrekt prehabilitáció időablaka bezárult.

Osztályunkon a mútét előtti (telefonos) felmérés rendszerét az országban elsóként dolgoztuk ki, táplálási teammunkával azóta a legnagyobb hazai tápláltságiállapot-adatbázist hoztuk létre. Módszerünk kórházi költséggel nem jár, viszont többkomponensű potenciális költségcsökkentő hatása van.

Míg egyes közlemények szerint a kórházakban fekvő összes beteg akár 30-50\%-a alultáplált lehet [18, 38], a sebészeti osztályos betegekre ez csak részben igaz. Az elektív, benignus betegség miatt mütétre várók <10\%-a tartozik rizikócsoportba [41]. A szolid malignus tumoros betegek közül az emlö- és endokrin sebészeti esetek ritkábban érintettek. A gastrointestinalis daganatos sebészeti betegeknél (különösen colorectalis, máj és pancreas) viszont a komplex felszívódási és passzázszavarok miatt ez az arány az irodalom szerint 40-60\% közötti [18, 23, 45, 48]. Kockázatfokozó az időskor, az akut mútét ténye és a beteg esetleges rossz szociális és gazdasági háttere [38].

Saját vizsgálatunk során még ennél is borúsabb képet kaptunk. Míg az NRS 2002 alapján az emlőtumoros betegek 95,2\%-ánál tápláltsági kockázat nem áll fenn, addig a tüdőreszekcióra várók 40,7\%-a, a májmútétre várók $43 \%$-a, a pancreasmalignitás (gyanúja) miatt operált betegek $80,9 \%$-a alultáplált (valószínú vagy biztos rizikócsoport). Az elektív, kuratív céllal végzett, malignus ok miatti colorectalis reszekciók $62,2 \%$-a, a palliatív beavatkozások 84\%-a, míg az akut gyomor-bél rendszeri mútétek $88 \%$-a alultáplált (valószínú vagy biztos rizikócsoport) betegeken történik. Az akut mütétre kerülő betegek mind az NRS 2002 értékben, mind a ClavienDindo-szövődményarányokban, mind a LOS-értékben a legkockázatosabb csoportot képezik.

Vizsgálatunkban az NRS 2002 értékek emelkedésével rendre nőtt a szövődmények aránya, tehát a szűrőmódszernek prediktív értéke van a kórjóslatra. Az NRS 2002 továbbá (nem szignifikáns léptékü) egyezést is mutat a stádiummal. Benignus hisztológia esetén mértük a legalacsonyabb átlagos NRS 2002 értéket, ennél magasabb volt a kuratív mútéteké. A legmagasabb értéket, ahogy az várható is, a palliatív mútétek csoportja hozta.

Telemedicina igénybevételével a hazai környezetben elsőként végzett összefoglaló tanulmányunk alapján megalapozottan javasoljuk, hogy a malignus tumor(gyanú) miatt tervezett hasi és mellkasi mútétek körében valamennyi palliatív/diagnosztikus és az összes pancreasoperáció előtt indokoltnak (és így támogatandónak) fogadják el a dietetikusi felmérést és az ezen alapuló megelőző, kiegészítő mesterséges táplálást. Ez a megállapítás természetesen nemcsak hogy nem váltja ki a tápláltsági állapot pontrendszeralapú rögzítését, de feltételül is szabja. Eredményeink a vizsgált akut mütéti esetekre is vonatkoznak, a kiegészítő mesterséges táplálás kötelme itt is fennáll. Az ellenőrzött tápszerfogyasztás kezdete ideálisan hetekkel előzi meg a mútétet. Az, hogy akut beavatkozás esetén ez nyilván nem valósítható meg, nem mentesít a közvetlen posztoperatív szakban való mérlegelés szükségessége alól.

A mütétre váró onkológiai betegek preoperatív tápláltságiállapot-felmérése tehát szükséges és a bemutatott győri modell alapján kivitelezhető is. Az NRS 2002 alapú szűrés rizikócsoportjai bizonyítottan jól korrelálnak a szövődménykategóriákkal. A szűrőmódszer telemedicinális alkalmazásával már a tervezett mütét előtt kiemelhetők a szövődmények szempontjából esendőbb betegek. A teszt objektív, reprodukálható, egyszerü és bármikor megismételhető jellegénél fogva elhanyagolható ráfordítás árán a klinikus segítségére van a perioperatív szak táplálási döntéshozatalában. A malnutritio szempontjából veszélyeztetett betegek mesterséges táplálással történő prehabilitációja az irodalmi adatok és saját tapasztalatunk alapján javítja a kimenetelt. Az esetleges hosszabb távú hatást további vizsgálataink tisztázzák.

Anyagi támogatás: A szerzők anyagi támogatásban nem részesültek.

Szerzői munkamegosztás: K. D.: A protokoll kidolgozása, adatgyújtés, cikkírás. B.-T. Z.: A protokoll kidolgozása, adatgyújjés. D. A.: Adatgyújtés, irodalomkutatás. M. F. T.: A protokoll kidolgozása, szakmai véleményezés. O. A.: A protokoll jóváhagyása, szakmai véleményezés. A cikk végleges változatát valamennyi szerző elolvasta és jóváhagyta.

Érdekeltségek: A szerzőknek nincsenek érdekeltségeik. 


\section{Köszönetnyilvánítás}

Köszönjük Gyurkovics Krisztinának és Horváth Katalinnak a dietetikusi felmérések elvégzését. Hálával tartozunk Geyer Timeának és Tóth Fruzsinának a felmérések adminisztratív terhének megkönnyítéséért. Köszönettel tartozunk dr. Barabás Bélának és dr. Lörincz M. Ákosnak a statisztikai számításokért.

\section{Irodalom}

[1] Dolan RD, McSorley ST, Horgan PG, et al. The role of the systemic inflammatory response in predicting outcomes in patients with advanced inoperable cancer: systematic review and metaanalysis. Crit Rev Oncol Hematol. 2017; 116: 134-146.

[2] Dolan RD, Laird BJ, Horgan PG, et al. The prognostic value of the systemic inflammatory response in randomised clinical trials in cancer: a systematic review. Crit Rev Oncol Hematol. 2018; 132: 130-137.

[3] Studley HO. Percentage of weight loss. A basic indicator of surgical risk in patients with chronic peptic ulcer. JAMA 1936; 106: 458-460.

[4] Rhoads JE, Alexander CE. Nutritional problems of surgical patients. Ann N Y Acad Sci. 1955; 63: 268-275.

[5] Durkin MT, Mercer KG, McNulty MF, et al. Vascular Surgical Society of Great Britain and Ireland: contribution of malnutrition to postoperative morbidity in vascular surgical patients. Br J Surg. 1999; 86: 702 .

[6] Weimann A, Braga M, Harsanyi L, et al. ESPEN Guidelines on Enteral Nutrition: surgery including organ transplantation. Clin Nutr. 2006; 25: 224-244.

[7] Yeh DD, Fuentes E, Quraishi SA, et al. Adequate nutrition may get you home: effect of caloric/protein deficits on the discharge destination of critically ill surgical patients. J Parenter Enteral Nutr. 2016; 40: 37-44.

[8] Pikul J, Sharpe MD, Lowndes R, et al. Degree of preoperative malnutrition is predictive of postoperative morbidity and mortal ity in liver transplant recipients. Transplantation 1994; 57: 469472 .

[9] van Bokhorst-de van der Schueren MA, van Leeuwen PA, Sauerwein HP, et al. Assessment of malnutrition parameters in head and neck cancer and their relation to postoperative complications. Head Neck 1997; 19: 419-425.

[10] Lukács G, Lelovics Zs, Oláh T, et al. Effects of modern nutrition and nurture on wound healing. [A korszerú táplálkozás és táplálás hatása a sebek gyógyhajlamára.] Studium \& Practicum 2011; 5: 7-10. [Hungarian]

[11] Hahn O, Harsányi L. Changes of body composition in malignant diseases. Science Med. 2011; 2: 361-367.

[12] Cheema FN, Abraham NS, Berger DH, et al. Novel approaches to perioperative assessment and intervention may improve longterm outcomes after colorectal cancer resection in older adults. Ann Surg. 2011; 253: 867-874.

[13] Valentini L, Volkert D, Schütz T, et al. Suggestions for terminology in clinical nutrition. e-Spen J. 2014; 9: e97-e108.

[14] Cederholm T, Bosaeus I, Barazzoni R, et al. Diagnostic criteria for malnutrition - an ESPEN consensus statement. Clin Nutr. 2015 ; 34 : $335-340$

[15] Harsányi L, Bukovácz R, Molnár Zs, et al. Importance of nutritional state in surgery. [A tápláltsági állapot jelentősége a sebészetben.] Magy Seb. 1998; 51: 357-360. [Hungarian]

[16] Rier HN, Jager A, Sleijfer S, et al. Low muscle attenuation is a prognostic factor for survival in metastatic breast cancer patients treated with first line palliative chemotherapy. Breast 2017; 31 : $9-15$.

[17] Weimann A, Braga M, Carli F, et al. ESPEN guideline: Clinical nutrition in surgery. Clin Nutr. 2017; 36: 623-650.
[18] Gur AS, Atahan K, Aladag I, et al. The efficacy of Nutrition Risk Screening-2002 (NRS-2002) to decide on the nutritional support in general surgery patients. Bratisl Lek Listy 2009; 110: 290-292.

[19] Suzuki S, Kanaji S, Yamamoto M, et al. Controlling Nutritional Status (CONUT) score predicts outcomes of curative resection for gastric cancer in the elderly. World J Surg. 2019; 43: 10761084 .

[20] Lukács G, Oláh T, Lelovics Z, et al. Modern clinical nutrition of oncologic patients. [Onkológiai betegek korszerü klinikai táplálása.] Onkológia 2012; 2: 111-114. [Hungarian]

[21] Kondrup J, Rasmussen HH, Hamberg O, et al. Nutritional Risk Screening (NRS 2002): a new method based on an analysis of controlled clinical trials. Clin Nutr. 2003; 22: 321-336.

[22] Sorensen J, Kondrup J, Prokopowicz J, et al. EuroOOPS: an international, multicentre study to implement nutritional risk screening and evaluate clinical outcome. Clin Nutr. 2008; 27: 340-349.

[23] Guo W, Ou G, Li X, et al. Screening of the nutritional risk of patients with gastric carcinoma before operation by NRS 2002 and its relationship with postoperative results. J Gastroenterol Hepatol. 2010; 25: 800-803.

[24] Dindo D, Demartines N, Clavien PA. Classification of surgical complications: a new proposal with evaluation in a cohort of 6336 patients and results of a survey. Ann Surg. 2004; 240: 205213.

[25] Katayama H, Kurokawa Y, Nakamura K, et al. Extended Clavien-Dindo classification of surgical complications: Japan Clinical Oncology Group postoperative complications criteria. Surg Today $2015 ; 46$ : 668-685

[26] Harsányi L, Horváth E. The importance and method of postoperative nutrition. [A posztoperatív táplálás jelentősége és gyakorlata.] Háziorv Továbbk Szle. 2009; 14: 144-147. [Hungarian]

[27] Wynter-Blyth V, Moorthy K. Prehabilitation: preparing patients for surgery. BMJ 2017; 358: j3702.

[28] Hijazi Y, Gondal U, Aziz O. A systematic review of prehabilitation programs in abdominal cancer surgery. Int J Surg. 2017; 39: 156-162.

[29] Sanchez-Lorente D, Navarro-Ripoll R, Guzman R, et al. Prehabilitation in thoracic surgery. J Thorac Dis. 2018; 10(Suppl 22): S2593-S2600.

[30] van Rooijen S, Carli F, Dalton S, et al. Multimodal prehabilitation in colorectal cancer patients to improve functional capacity and reduce postoperative complications: the first international randomized controlled trial for multimodal prehabilitation. BMC Cancer 2019; 19: 98.

[31] Gillis C, Buhler K, Bresee L, et al. Effects of nutritional prehabilitation, with and without exercise, on outcomes of patients who undergo colorectal surgery: a systematic review and metaanalysis. Gastroenterology 2018; 155: 391-410.e4.

[32] Csiba B, Nagy Á, Lukovich P, et al. Nutritional state, identifying sarcopenia and the importance of prehabilitation in the treatment of oncologic surgery patients. [Tápláltsági állapot, sarcopenia felismerése és a prehabilitáció jelentősége daganatos betegek sebészeti kezelése kapcsán.] Lege Artis Med. 2020; 30: 123128. [Hungarian]

[33] Harsányi L. New strategies in artificial nutrition. [Új stratégiák a mesterséges táplálásban.] Metabolizmus 2010; 8: 248-251. [Hungarian]

[34] Health Professional College. Healthcare professional guideline. Hungarian protocoll for nutrition therapy of adult patiets in hospitals. [Egészségügyi Szakmai Kollégium. Egészségügyi szakmai irányelv - A kórházi, az egészségügyi ápolási otthonokban és az otthon ellátásra szoruló felnőtt betegek tápláltsági állapotának felmérése és a tápláltsági zavarok táplálásterápiával történő kezeléséről.] Klinikai egészségügyi szakmai irányelv azonosítója: 001267. [Hungarian] 
[35] Harsányi L, Varga P, Bodoky G. State of artificial nutrition in Hungary: standpoint and methodologic recommendations. Nutrition 1999; 15: 40-43.

[36] Grass F, Cerantola Y, Schäfer M, et al. Perioperative nutrition is still a surgical orphan: results of a Swiss-Austrian survey. Eur J Clin Nutr. 2011; 65: 642-647.

[37] Schindler K, Pernicka E, Laviano A, et al. How nutritional risk is assessed and managed in European hospitals: a survey of 21,007 patients findings from the 2007-2008 cross-sectional nutritionDay survey. Clin Nutr. 2010; 29: 552-559.

[38] Cerantola Y, Grass F, Cristaudi A, et al. Perioperative nutrition in abdominal surgery: recommendations and reality. Gastroenterol Res Pract. 2011; 2011 : 739347.

[39] Guo XW, Zhu L, Ye HX, et al. Effect of preoperative Nutritional Risk Screening - 2002 combined with hematologic inflammatory markers on prognosis of thoracic esophageal squamous cell carcinoma. Zhonghua Zhong Liu Za Zhi 2019; 41: 604-609. [Chinese]

[40] Sun HJ, Guo XW, Ji SJ, et al. Prognostic influence of preoperative Nutritional Risk Screening - 2002 (NRS-2002) score for patients with thoracic esophageal squamous cell carcinoma receiving surgery. Zhonghua Zhong Liu Za Zhi 2018; 40: 917921. [Chinese]

[41] Schiesser M, Müller S, Kirchhoff P, et al. Assessment of a novel screening score for nutritional risk in predicting complications in gastro-intestinal surgery. Clin Nutr. 2008; 27: 565-570.

[42] Wu LM, Zhou FR, Lin QF, et al. Impact of nutritional status on postoperative outcomes for patients with colorectal cancer.
Zhonghua Wei Chang Wai Ke Za Zhi 2011; 14: 271-274. [Chinese]

[43] Liu H, Hu YF, Liu H, et al. Association between the score of preoperative nutritional risk screening and anastomotic leakage following anterior resection for the rectal cancer. Zhonghua Wei Chang Wai Ke Za Zhi 2013; 16: 552-554. [Chinese]

[44] Fei B, Pan J, Wu H, et al. Application of preoperative nutritional risk screening in perioperative nutrition support for colorectal cancer patients. Zhonghua Wei Chang Wai Ke Za Zhi 2014; 17: 582-585. [Chinese]

[45] Sun Z, Kong XJ, Jing X, et al. Nutritional risk screening 2002 as a predictor of postoperative outcomes in patients undergoing abdominal surgery: a systematic review and meta-analysis of prospective cohort studies. PLoS ONE 2015; 10: e0132857.

[46] Dou L, Wang X, Cao Y, et al. Relationship between postoperative recovery and nutrition risk screened by NRS 2002 and nutrition support status in patients with gastrointestinal cancer. Nutr Cancer 2020; 72: 33-40.

[47] Benoit M, Grass F, Demartines N, et al. Use of the nutritional risk score by surgeons and nutritionists. Clin Nutr. 2016; 35: 230-233.

[48] Harsányi L. Clinical nutrition in liver and pancreatic diseases. Acta Chir Hung. 1999; 38: 269-277.

(Kollár Dániel dr., Győr, Vasvári Pál út 2-4., 9024 e-mail: kollardani@gmail.com)

\section{„Inter omnes partes medicinae chirurgia effectus evidentissmus." (Az orvostudomány összes ága közül a sebészet eredménye a legnyilvánvalóbb.)}

A cikk a Creative Commons Attribution 4.0 International License (https://creativecommons.org/licenses/by/4.0/) feltételei szerint publikált Open Access közlemény, melynek szellemében a cikk bármilyen médiumban szabadon felhasználható, megosztható és újraközölhetö, feltéve, hogy az eredeti szerző és a közlés helye, illetve a CC License linkje és az esetlegesen végrehajtott módosítások feltüntetésre kerülnek. (SID_1) 